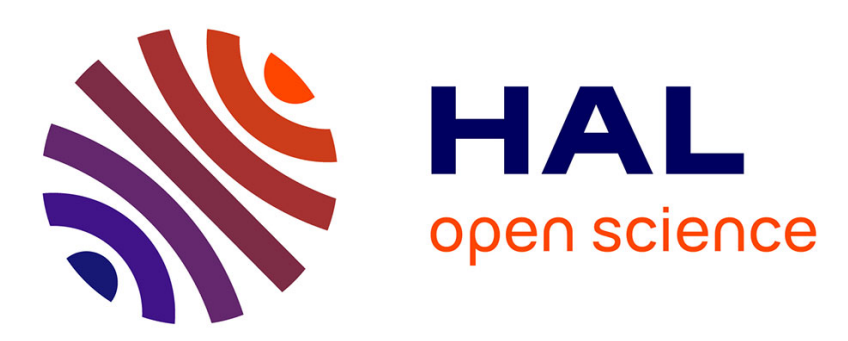

\title{
Impact of organic amendments and compost extracts on tomato production and storability in agroecological systems
}

\author{
R. Ghorbani, A. Koocheki, M. Jahan, G.A. Asadi
}

\section{> To cite this version:}

R. Ghorbani, A. Koocheki, M. Jahan, G.A. Asadi. Impact of organic amendments and compost extracts on tomato production and storability in agroecological systems. Agronomy for Sustainable Development, 2008, 28 (2), pp.307-311. hal-00886442

\section{HAL Id: hal-00886442 \\ https://hal.science/hal-00886442}

Submitted on 1 Jan 2008

HAL is a multi-disciplinary open access archive for the deposit and dissemination of scientific research documents, whether they are published or not. The documents may come from teaching and research institutions in France or abroad, or from public or private research centers.
L'archive ouverte pluridisciplinaire HAL, est destinée au dépôt et à la diffusion de documents scientifiques de niveau recherche, publiés ou non, émanant des établissements d'enseignement et de recherche français ou étrangers, des laboratoires publics ou privés. 


\title{
Impact of organic amendments and compost extracts on tomato production and storability in agroecological systems
}

\author{
R. GHORBANI ${ }^{1 *}$, A. KOOCHEKI ${ }^{1}$, M. JAHAN ${ }^{1}$, G.A. ASADI ${ }^{2}$ \\ ${ }^{1}$ Department of Agronomy, Faculty of Agriculture, Ferdowsi University of Mashhad, PO Box 91775-1163, Mashhad, Iran \\ ${ }^{2}$ Shiravan College of Agriculture, Ferdowsi University of Mashhad, Shiravan, Iran
}

(Accepted 8 January 2008)

\begin{abstract}
The sustainability of a farm system greatly relies on fertilizers and other inputs. Soil factors such as texture and local rainfall, along with management-related factors such as soil organic matter, aggregate stability and agronomic practices, have much greater influence on the sustainability of any given farm than do the type or amount of soil amendments. Growers use a wide variety of practices to maintain or improve soil health in organic vegetable production systems. These practices generally are part of long-term, site-specific management programs that aim at developing fertile and biologically active soils that readily capture and store water and nutrients, have good tilth, and suppress plant diseases. Field experiments were conducted in 2005 and 2006 in Mashhad, Iran, to study the effects of organic amendments, synthetic fertilizers and compost extracts on crop health, productivity and storability of tomato (Lycopersicon esculentum Mill.). Treatments included different fertilizers of cattle, sheep and poultry manures, green-waste and household composts and chemical fertilizers of urea and superphosphate; and five aqueous extracts from cattle manure, poultry manures, green-waste, and household composts plus water as control. Our results show that application of poultry manure showed lower disease incidence, as shown by $80 \%$ healthy tomato, compared with the other fertilizers. However, the organic fertilizers used did not give higher yields compared with chemical fertilizers. Sheep manure and chemical fertilizers led to the highest total tomato yield. Marketable yield was highest in poultry manures, of $16 \mathrm{t} / \mathrm{ha}$, and lowest in chemical fertilizer, of $7 \mathrm{t} / \mathrm{ha}, 6$ weeks after storage. The effect of aqueous extracts was not significant on either crop health or tomato yield and the results were inconsistent. The compost made of poultry manure therefore appears to be a promising ecological alternative to classical fertilizers.
\end{abstract}

compost / crop health / lycopersicum esculentum / manure / marketable yield

\section{INTRODUCTION}

Ensuring a sustained supply of wholesome, fresh and healthy food while maintaining ecological or environmental integrity and social harmony has become a major challenge and a central issue in the agricultural sector for researchers, producers and policy-makers. One of the most important principles for making a farm more sustainable is reducing the use of synthetic fertilizers by increasing on-farm nutrient cycling and preventing pests and diseases by building healthy and biologically active soil (Neeson, 2004). The problems associated with the use of hazardous chemicals for crop protection, weed control and soil fertility are receiving increasing attention worldwide since pests, diseases and weeds become resistant to chemical pesticides and environmental pollution and ecological imbalances may occur. Therefore, non-renewable

\footnotetext{
*Corresponding author: bot155@hotmail.com
}

petrochemical resources should be replaced by biologicallybased renewable inputs (Quimby et al., 2002). Sustainability in agroecosystems involves environmentally-friendly techniques based on biological and non- chemical methods (Bonato and Ridray, 2007). Sustainable and organic tomato disease control programs are based on a combination of organic soil management practices, IPM practices, natural remedies and limited fungicide use. Application of composts, crop rotations including legumes, and supplemental fertilization with organic materials are soil management practices that form the basis of biological disease control of soil-borne pathogens (Lumsden, 1983; Hoitink and Fahy, 1986).

Tomato is grown by using conventional as well as organic fertilizers. However, fertilizer sources can have a significant effect on tomato quality (Toor et al., 2006). On the other hand, there is growing interest in using organic amendments and compost extracts to improve soil conditions and prevent crop diseases in tropical, arid and temperate climates 
(Litterick et al., 2004). Organic farmers often use composts as soil amendments, particularly in intensive vegetable production systems to improve soil fertility and quality, and sustain productivity. Composts improve biological, chemical and physical properties of amended soils and can provide effective biological control of diseases caused by plant pathogens. They may also reduce the severity of diseases caused by foliar plant pathogens (Abbasi et al., 2002). Using organic fertilizers, composts and additions of rock minerals not only supplies plant nutrients but increases tolerance and resistance to insects and diseases, helps control weeds, retains soil moisture, and ensures produce quality (Barker and Bryson, 2006; Diver et al., 1999; Montemurro et al., 2005; Zhang et al., 1998). The components of composts responsible for this induced activity may be biological or chemical in nature (Zhang et al., 1998). Various alternative treatments, including microbial antagonists and plant or compost extracts, have been developed for the control of plant pathogens. They may have direct anti-disease effects or stimulate competitor micro-organisms and/or induce plant resistance (Ghorbani et al., 2006). Liquid pig manure, matured cattle manure and sugarcane husks applied directly to the soil showed promising results for control of some crop diseases (DeCeuster and Hoitink, 1999; Viana et al., 2000). However, there are reports suggesting that using organic fertilizers increased development of some diseases. For example, Chauhan et al. (2000) found that increasing application of farm yard manure from 25 to $75 \mathrm{t} /$ ha increased disease severity of stem rot (Rhizoctonia solani) in cauliflower.

Compost extracts, which are filtrated solutions of mixtures of compost materials and water, have shown promising results against crop diseases (Brinton et al., 1996; Goldstein, 1998) but the mechanisms of effects seem to vary depending on the host/pathogen relationship and the mode of application. Compost extracts were reported to show good activity against some plant diseases, especially when enriched with selected microbial antagonists (Weltzien, 1989). Goldstein (1998) reported that composts and compost extracts activate diseaseresistance genes in plants. These genes are activated in response to the presence of a pathogen. They mobilize chemical defences against the pathogen invasion, although often it is too late to avoid the disease. Plants growing in compost may have these disease-prevention systems already running (Sullivan, 2001). Brinton et al. (1996) examined compost teas for controlling plant pathogenic fungi such as late blight in potatoes. They found that the key factors influencing effectiveness were the age of the compost (extracts from older composts were more effective than those from younger composts), and the nature of its source ingredients. Indications of a systemic whole-plant response to composts that are disease-suppressive have been reported for several vegetables (Logsdon, 1995; Ghorbani et al., 2006). The effects of compost application either as extracts to the foliage or as soil amendments on plant disease control may be due to direct antipathogen or resistance-inducing/plant-strengthening effects. However, the mechanisms by which compost extracts work are not well known, but seem to vary depending on the host/pathogen relationship and the mode of application. It is believed that
Table I. Selected soil properties of the experimental field.

\begin{tabular}{lcc}
\hline & \multicolumn{2}{c}{ Soil depth $(\mathrm{cm})$} \\
\cline { 2 - 3 } & $0-15$ & $15-30$ \\
\hline Texture & Silty loam & Silty loam \\
Water storage capacity $(\%)$ & 24.17 & 18.18 \\
Bulk density $\left(\mathrm{kg} . \mathrm{m}^{3}\right)$ & 1430 & 1550 \\
pH (saturation extract) & 7.8 & 7.8 \\
Organic C (\%) & 0.57 & 0.52 \\
Total N (\%) & 0.045 & 0.045 \\
C/N & 12.4 & 11.5 \\
Available P $(\mathrm{ppm})$ & 3.0 & 2.0 \\
Available K $\left(\mathrm{kg}^{3} \mathrm{ha}^{-1}\right)$ & 470 & 420 \\
\hline
\end{tabular}

the overall activity of alternative crop disease treatments may be improved by combining compatible/synergistic extract preparations and/or biological control agents (Ghorbani et al., 2006).

There is limited information on the effect of different forms of fertilizers on tomato production and storability in arid and semi-arid climates. Therefore, the objectives of this study were to determine the effects of different forms of fertilizers (mineral and organic forms) and different compost extracts from different types of feed-stocks on tomato production and storability. Our hypothesis was that supplying nutrients from different sources of fertilizers would affect the production of fresh tomato, and also tomato health in stores.

\section{MATERIALS AND METHODS}

The study was carried out in the Field Research Stations of Ferdowsi University of Mashhad, North-East of Iran, located at $36^{\circ} 15^{\prime}$ North latitude and $59^{\circ} 28^{\prime}$ 'East longitude of Iran during the two growing seasons of 2005 and 2006. The experiments were designed as split plots based on a complete randomized block design with three replications. The soil type of the experimental field was sandy clay loam with a $\mathrm{pH}$ of 7 to 8 and 0.5 organic matter (Tab. I). Treatments, including different kinds of soil amendments, cattle, sheep and poultry manures, green-waste compost, household compost and chemical fertilizers of urea and superphosphate, were assigned to main plots and five extracts from cattle manure, poultry manure, green-waste, and household composts plus water as control were placed in sub-plots.

Deep moldboard ploughing was applied to the whole trial field in autumn. Three weeks before transplanting tomato, six different soil amendments were applied and immediately after that a rotary cultivator was used. Based on the results of soil tests, $160 \mathrm{~kg} / \mathrm{ha}$ of nitrogen and $125 \mathrm{~kg} / \mathrm{ha}$ phosphorus (Heeb et al., 2005) were provided by using chemical fertilizers of urea and superphosphate at seed bed preparation. The applied quantities of organic fertilizers were based on usual application by local farmers, $20 \mathrm{t} / \mathrm{ha}$. The characteristics of the organic fertilizers used as soil amendments are shown in Table II. Each sub-plot contained 4 rows $75 \mathrm{~cm}$ apart and four meters in length. Tomato seeds of the super-Quinn variety were planted and grown in a field of loamy sand soil 
Table II. Characteristics of organic fertilizers used as soil amendments.

\begin{tabular}{lccccc}
\hline & $\mathrm{N}$ & $\mathrm{P}$ & $\mathrm{K}$ & $\mathrm{Ca}$ & $\mathrm{Mg}$ \\
& $(\%)$ & $(\%)$ & $(\%)$ & $(\%)$ & $(\%)$ \\
\hline Cattle manure & 2.36 & 0.59 & 2.08 & 2.16 & 0.46 \\
Sheep manure & 1.55 & 0.61 & 2.03 & 3.20 & 0.48 \\
Poultry manure & 0.95 & 1.22 & 1.03 & 10.0 & 0.96 \\
Household compost & 1.30 & 0.44 & 0.49 & 8.00 & 0.84 \\
\hline
\end{tabular}

under a plastic tunnel for six weeks. Plant seedlings were hand-transplanted to the irrigated field in the second week of April in both years. Tomatoes were irrigated immediately after transplanting and then once a week until the end of fruiting. Hoe re-ridging was undertaken manually using a locally manufactured hoe two weeks after transplanting. No chemical pesticides were used and weeds were controlled by hand in both years. During the growing season, tomato plots were regularly observed and any disease, pest or disorders were recorded based on the percentage of necrotic or disordered plants (James et al., 1972). Two weeks before the third harvest, tomato plants were assessed for general health based on the percentage of non-healthy plants in each plot. To determine tomato yield, $9 \mathrm{~m}^{2}$ in the middle of each plot was marked and tomato fruits were picked and weighed three times when they had reached maturity stage 5 (Californian Tomato Commission, 2002) during July and August. In order to assess the tomato storability, a sample size of $10 \mathrm{~kg}$ from the third harvest was taken from each plot, weighed and stored at $\operatorname{cool}\left(4-7^{\circ} \mathrm{C}\right)$ temperatures for 6 weeks. Percentages of diseased and healthy tomato were determined after 6 weeks' storage and then marketable yield was evaluated based on this percentage and the total yield of three harvests.

Composts and manures were extracted with water 48 hours before use in the field. Locally produced composts and manures were put in a barrel, then the barrel was topped off with tepid water $(1: 10 \mathrm{~W} / \mathrm{V})$. The extract was allowed to ferment at ambient temperatures for 48 hours. The finished product was strained through two layers of cheesecloth and used as a foliar spray. The watery compost extracts were applied twice at the beginning of flowering and the beginning of tomato fruit production. Results from each plot were converted into a ton per hectare for analysis and presentation. Data were analyzed by analysis of variance (ANOVA) and regression. Data in percentage units (assessments of diseased tomato) were transformed $\left(\log _{10}\right.$ of $\left.[\mathrm{x}+0.5]\right)$ before further analysis to normalize the data. The means were compared by using Tukey's Honestly Significant Difference test to identify homogenous groups within the means $(P<0.05)$ with MS Excel and Minitab statistical software. The probability level for determination of significance was 0.05 .

\section{RESULTS AND DISCUSSION}

\subsection{General health of tomato plants}

Using organic fertilizers such as animal manures, composts and by-product materials not only could supply plant nutri-

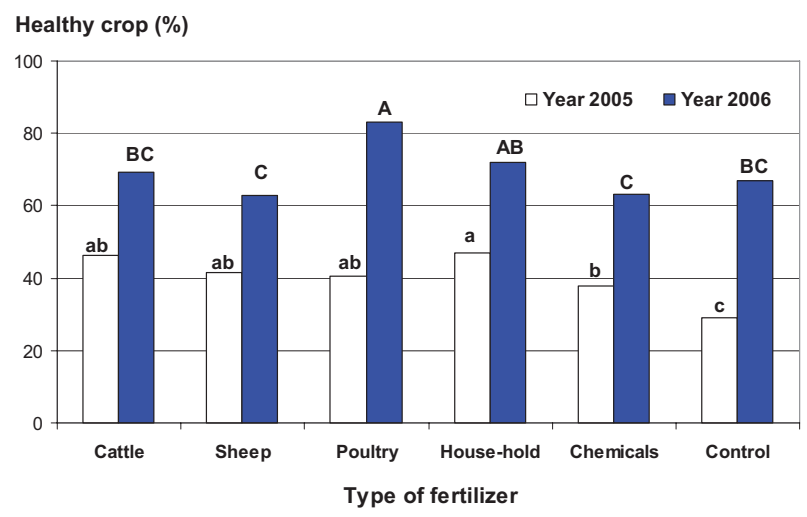

Figure 1. Effects of soil amendments on tomato general health during the two-year trial. Each point represents the mean of 15 observations and different letters indicate significant differences $(P<0.05)$ according to Tukey's Honestly Significant Difference test.

ents, but can increase tolerance and resistance to insects and diseases, help control weeds, retain soil moisture, and ensure produce quality (Barker and Bryson, 2006). The results of tomato general health (pathogenically or physiologically diseased) in this investigation showed that the effects of soil amendments and extracts on tomato health were not significant in the first year of the experiment (Fig. 1). However, the effect of type of soil amendment was significant $(P<0.05)$ during 2006. No significant diseases occurred, but early blight and fruit rot caused by Alternaria solani, septoria leaf spot, bacterial canker and late blight were the most commonly observed tomato diseases in the field.

Plots with poultry manure showed significantly lower disease incidence (less than 20\%) compared with the other soil amendments. Since no chemical pesticides were used against pests and diseases, the incidence level of foliage diseases on average was 50-60\% in 2005 and 30-40\% of plants in 2006. Ecological and organic farmers have to tolerate a field that is not pest- and disease-free, and therefore should be patient and trade short-term economic returns for longer-term "ecological" credits while building soil health. The effects of aqueous extracts and types of soil amendments were very limited, inconsistent and non-significant on crop health. The achievement of consistent effects depends upon producing extracts that are exactly the same from batch to batch from an individual compost feed-stock (Ghorbani et al., 2006). Composts' contribution to nutrient fertility must also be taken into account because nutrient effects may influence the severity of pathogens (Phukan, 1993). In this regard, the slower rate of nutrient availability and mineralization from the organic fertilizers should also be considered (Sharma and Sharma, 2004). Plants with poultry manure were healthier than others and this might be related to higher levels of $\mathrm{P}$ and $\mathrm{Ca}$ compared with the other soil amendments (Tab. II). The use of organic soil amendments can result in a better soil quality and greater plant disease suppressiveness (Bulluck and Ristaino, 2002); however, in this study it depended on the type of organic fertilizer.

There are references showing that fertilization with organic amendments caused lower populations of pests in tomato than the population grown on the synthetic fertilizers, indicating 


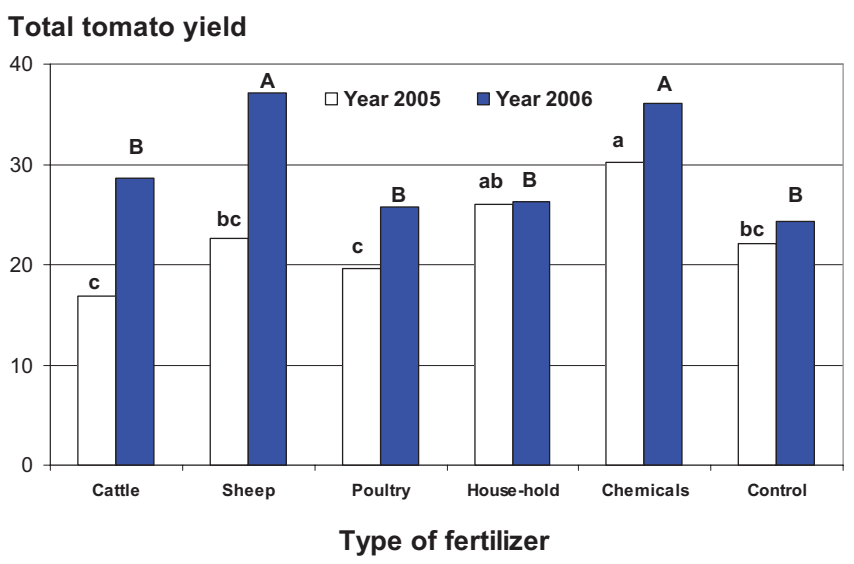

Figure 2. Effects of different soil amendments on total tomato yield ( $\mathrm{t} / \mathrm{ha}$ ). Each point represents the mean of 15 observations and different letters indicate significant differences $(P<0.05)$ according to Tukey's Honestly Significant Difference test.

that organic fertilizers may have the potential to reduce pest attacks in the long term (Yardim and Edwards, 2003). However, in the present study application of either organic or synthetic fertilizers did not increase pest populations in tomatoes in both years.

\subsection{Tomato yield}

The analysis of variance results showed that the effect of fertilizer type on tomato yield was significant in both years $(P=0.003)$; however, the effects of various compost extracts $(P=0.156)$ and interaction between fertilizer type and compost extracts were not significantly different $(P=0.153)$. The organic fertilizers used did not obtain higher yields compared with using chemical fertilizers, and sheep manure led to the highest total tomato yield (Fig. 2). Except the sheep manure treatment, yields of tomatoes from the organically fertilized plants were significantly lower than yields from plants that received mineral fertilizer. This might be due to the fact that organic fertilizers release nutrients more slowly than mineral fertilizers, resulting in decreased $\mathrm{S}$ and $\mathrm{P}$ concentrations in the leaves, which limited growth and yield in the organic fertilizers (Heeb et al., 2006). The improvements in plant growth and increases in fruit yields in organic amendments could also be due partially to large increases in soil microbial biomass after organic fertilizer applications, leading to production of hormones or humates in the composts acting as plant-growth regulators independent of the nutrient supply (Arancon et al., 2003; Tu, et al., 2006). However, as Barker and Bryson (2006) suggested, fertilization with composts might be more beneficial for increasing plant growth when the compost is enriched with nutrients. Overall, it can be concluded that an appropriate nutrient supply, either organic or mineral, is crucial to reach high yields in tomato. In this study, sheep manure, similarly to mineral fertilizers, significantly increased tomato yield by at least $10 \mathrm{t} / \mathrm{ha}$, specially in the second year of the experiment. However, storability and marketable yield of tomato might be different between various soil amendments.

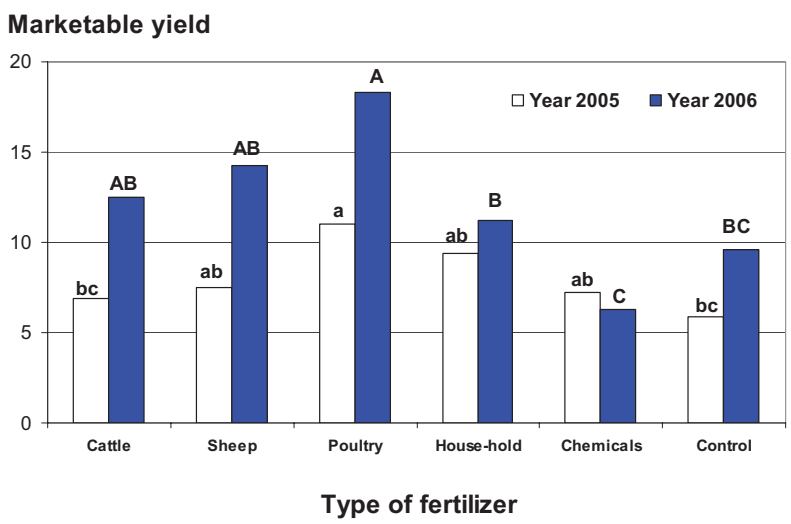

Figure 3. Effects of different soil amendments on total tomato marketable yield (t/ha) after keeping for 6 weeks in storage. Each point represents the mean of 15 observations and different letters indicate significant differences $(P<0.05)$ according to Tukey's Honestly Significant Difference test.

\subsection{Tomato storability}

Application of organic fertilizers improved tomato storability (Fig. 3). The effects of compost extracts were inconsistent and non-significant on fruit health and marketable yield after 6 weeks in storage. However, the effects of the type of fertilizer on post-harvest behavior of tomato were significant $(P<0.05)$. Healthy marketable yield for organic fertilizer treatments was at least twice that of the chemical fertilizer treatment. Chemical fertilizer neither changed nor decreased tomato storability. Easily available and excessive nitrogen fertilization delays maturity and may reduce tomato yield. Delayed maturity results in foliage exposed to potential infection for a longer time, increasing the risk of fruit diseases. Crops grown with higher doses of nitrogen tend to rot and sprout earlier during storage (Kumar et al., 2007). The use of unnecessarily high rates of $\mathrm{N}$ fertilization may also have an adverse effect on the environment (increasing the potential rate of nitrate leaching), resulting in higher costs of production. On the other hand, too low applications of $\mathrm{N}$ fertilizer can adversely affect the crop, e.g. reducing growth and yield or delaying maturity and compromising storability. In addition to the nitrogen level, higher storability in poultry treatments might be related to higher phosphorus and calcium concentrations. As we can see in Table II, poultry and household composts both contained similar and high concentrations of calcium, but poultry, which had higher phosphorus as well, showed significantly higher storability and therefore phosphorous could be the main reason for higher storability in tomato grown in poultry manures. Hachicha et al. (2006) found that compost made of poultry manure appears to be a promising ecological alternative to classical fertilizers. Our results also showed that among the different tested fertilizers, poultry manures showed the least total disease incidence and showed a promising performance for improving storage life. Whether this improvement in storability is due to thicker skin and less acidic juice and/or lower water content and higher pulp content has not been investigated. 


\section{CONCLUSION}

We studied the short-term effects of organic-based and chemical fertilizers on crop performance and tomato marketable yield in low-input and ecological systems. The results showed that optimal quality and quantity of tomato fruits and desired sensory shelf life are affected by production inputs. Application of sheep manures showed the highest yield, over $30 \mathrm{t} / \mathrm{ha}$. However, organic amendments of poultry showed a significant impact on crop health, post-harvest quality and tomato storage life. Although all the organic fertilizers generally showed quite a stimulation of tomato yield and storability, poultry manure was superior to all other organic manures in terms of tomato storability and final marketable yield after six weeks' storage. Therefore, based on the results of these experiments, application of sheep manure, similarly to mineral fertilizers, caused an average of $5 \mathrm{t} /$ ha higher yield. However, in the case where the aim of the tomato production is being processed and/or being used in another season, incorporation of poultry manure and household compost in soil could be a viable alternative to chemicals for improving tomato shelf life in stores.

Acknowledgements: The authors wish to acknowledge Ferdowsi University of Mashhad for financial support, and providing the experimental field, materials and storage facilities. The authors also wish to thank Dr. M. Nassiri for his help and advice on statistical analysis.

\section{REFERENCES}

Abbasi P.A., Al-Dahmani J., Sahin F., Hoitink H.A.J., Miller S.A. (2002) Effect of compost amendments on disease severity and yield of tomato in conventional and organic production systems, Plant Dis. $86,156-161$.

Arancon N.Q., Edwards C.A., Bierman P., Metzger J.D., Lee S., Welch C. (2003) Effects of vermicomposts on growth and marketable fruits of field-grown tomatoes, peppers and strawberries, Pedobiologia 47, 731-735.

Barker A.V., Bryson G.M. (2006) Comparisons of composts with low or high nutrient status for growth of plants in containers, Commun. Soil Sci. Plan. 37, 1303-1319.

Bonato O., Ridray G. (2007) Effect of tomato deleafing on mirids, the natural predators of whiteflies, Agron. Sustain. Dev. 27, 167-170.

Bulluck L.R., Ristaino J.B. (2002) Effect of synthetic and organic soil fertility amendments on southern blight, soil microbial communities, and yield of processing tomatoes, Phytopathology 92, 181-189.

Brinton W.F., Trankner A., Roffner M. (1996) Investigations into liquid compost extracts, Biocycle 37, 68-70.

Californian Tomato Commission (2002) Retrieved September 2000 from the World Wide Web: http://www.tomato.org/retail/color.html.

Chauhan R.S., Maheshwari S.K., Gandhi S.K. (2000) Effect of nitrogen, phosphorus and farm yard manure levels on stem rot of cauliflower caused by Rhizoctonia solani, Agr. Sci. Digest. 20, 36-38.

De Ceuster T.J.J., Hoitink H.A.J. (1999) Using compost to control plant diseases, BioCycle 40, 61-63.

Diver S., Kuepper G., Born H. (1999) Organic tomato production. ATTRA // Organic Tomato Production.

Ghorbani R., Wilcockson S., Leifert C. (2006) Alternative treatments for late blight control in organic potato: Antagonistic micro-organisms and compost extracts for activity against Phytophthora infestans, Potato Res. 48, 171-179.

Goldstein J. (1998) Compost suppresses disease in the lab and on the fields, BioCycle 39, 62-64.
Hachicha S., Chtourou M., Medhioub K., Ammar E. (2006) Compost of poultry manure and olive mill wastes as an alternative fertilizer, Agron. Sustain. Dev. 26, 135-142.

Heeb A., Lundegaardh B., Ericsson T., Savage G.P. (2005) Nitrogen form affects yield and taste of tomatoes, J. Sc. Food Agr. 85, 1405-1414.

Heeb A., Lundegaardh B., Savage G., Ericsson T. (2006) Impact of organic and inorganic fertilizers on yield, taste, and nutritional quality of tomatoes, J. Plant Nutr. Soil Sc. 169, 535-541.

Hoitink H.A., Fahy P.C. (1986) Basis for the control of soilborne plant pathogens with composts, Annu. Rev. Phytopathol. 24, 93-114.

James, W.C., Shih, C.S., Hodgson W.A., Callbeck L.C. (1972) The quantitative relationship between late blight of potato and loss in tuber yield, Phytopathology 62, 92-96.

Kumar S., Imtiyaz M., Kumar A. (2007) Effect of differential soil moisture and nutrient regimes on postharvest attributes of onion (Allium cepa L.), Scientia Horticulturae 112, 121-129.

Litterick A.L., Harrier L., Walllace P., Watson C.A., Wood M. (2004) The role of uncomposted materials, composts, manures, and compost extracts in reducing pest and disease incidence and severity in sustainable temperate agricultural and horticultural crop production - a review, Crit. Rev. Plant Sci. 23, 453-479.

Logsdon G. (1995) Using compost for plant disease control, pp. 5860 in: Farm Scale Composting. BioCycle magazine/The JG Press, Emmaus, PA.

Lumsden R.D. (1983) Effect of organic amendments on soilborne plant diseases and pathogen antagonists, pp. 51-70. in: Lockeretz, William (ed.), Environmentally Sound. Agriculture (Selected Papers from the Fourth International Conference of IFOAM), Praeger Press, New York, NY.

Montemurro F., Convertini G., Ferri D., Maiorana M. (2005) MSW compost application on tomato crops in Mediterranean conditions: Effects on agronomic performance and nitrogen utilization, Compost Sci. Util. 13, 234-242.

Neeson R. (2004) Organic processing tomato production. Agfact H8.3.6, 1 st ed.

Phukan S.N. (1993) Effect of plant nutrition on the incidence of late blight disease of potato in relation to plant age and leaf position, Indian J. Mycol. Plant Pathol. 23, 287-290.

Quimby P.C., King L.R., Grey W.E. (2002) Biological control as a means of enhancing the sustainability of crop/land management systems, Agr. Ecosyst. Environ. 88, 147-152.

Sharma A., Sharma J.J. (2004) Influence of organic and inorganic sources of nutrients on tomato (Lycopersicon esculentum) under high hill dry temperate conditions, Indian J. Agr. Sci. 74, 465-467.

Sullivan P. (2001) Sustainable management of soil-born plant diseases. ATTRA, USDA's Rural Business Cooperative Service. Available from: www.attra.org.

Toor R.K., Savage G.P., Heeb A. (2006) Influence of different types of fertilizers on the major antioxidant components of tomatoes, J. Food Comp. Anal. 19, 20-27.

Tu C., Ristaino J.B., Hu S. (2006) Soil microbial biomass and activity in organic tomato farming systems: Effects of organic inputs and straw mulching, Soil Biol. Biochem. 38, 247-255.

Viana F.M.P., Kobory R.F., Bettiol W., Athayde S.C. (2000) Control of damping-off in bean plant caused by Sclerotinia sclerotiorum by the incorporation of organic matter in the substrate, Summa Phytopathologica. 26, 94-97.

Weltzein H.C. (1989) Some effects of composted organic materials on plant health, Agr. Ecosyst. Environ. 27, 439-446.

Yardim E.N., Edwards C.A. (2003) Effects of organic and synthetic fertilizer sources on pest and predatory insects associated with tomatoes, Phytoparasitica 31, 324-329.

Zhang W., Han D.Y., Dick W.A., Davis K.R., Hoitink H.A.J. (1998) Compost and compost water extract-induced systemic acquired resistance in cucumber and Arabidopsis, Phytopathology 88, 450455. 